\title{
Ways to Improve Judicial Protection System of Human Rights
}

\author{
Zhu Yong(Hainan Vocational College of Politics and Law, Haikou city of hainan province,571100)
}

Key words: Human rights; Perfect; Security system

Abstract: In social life, we both have obligations and rights. Judicial guarantee for human rights is both the happiness people always pursue, and the goal for which communist party of China has been unremitting striving. For the respect for human rights, a corresponding system of judicial protection of human rights has been written to the highest authority of law, The Constitution, in China. However, there are still some holes need to be perfected so as to better serve the people.

Human rights, just as its name implies, refers to the rights of man. In China, a country under the rule of law, human rights are not only the most basic starting point and final destination of law rule, but a judicial basis for right standard judgment and value in the reform. China is a country with profound respect for human rights, and has achieved good results in the judicial protection of human rights system. Though, the continuous development of society makes the increase in people's demand for right, and some level of the original justice of human rights in social security system cannot satisfy it, and there are some problems need to be solved rapidly. Therefore, this article studies and makes instructions on the improvement of the judicial protection of human rights on the basis of nowadays society.

\section{IDENTIFY THE INNER NATURE OF THE JUDICIAL PROTECTION OF HUMAN RIGHTS}

For judicial guarantee for human rights, some people understand from elaborating its literal and think it is to use legal system to protect human rights. Such simple surface meaning in a certain extent distorts the real meaning of judicial protection of human rights. Long ago in the ancient society, judicial right was also used to protect the lawful rights and interests of the people. When crimes happen, the rights and interests of the victim will get the protection and security. But when punishing criminal offenders, their human rights are ignored, let alone using a single criminal to exclude all others for the whole group as well as the whole family. After the concept of human rights, which came from the democratic revolution from bourgeois, was put forward, they believe that everything people born with, including people's lives, physical health, each person's property, freedom and dignity, is the human right which should be protected by law. So for judicial protection of human rights, the most basic is not only to pay attention to and protect the victim's personal rights and interests, also protect the basic rights and interests of the victim to ensure the accused person's human rights not to be trampled in the process of handling criminal cases. This shows that our country judicial protection of human rights not only makes a harsh crackdown on illegal crime, and at the same time, in a certain extent, protects personal rights and interests to obtain fair and justice. But with the development of the time and the progress of social science and culture, human rights are not confined to the original life rights protection, but developed into collective rights, political interests, economic and cultural rights and interests, so that every Chinese citizen can feel the judicial justice and fairness, and judicial justice can serve the people with heart.

\section{FIRM BELIEF OF HUMAN RIGHTS PROTECTION}

The improvement of judicial protection system of human rights is to firmly set up the idea of human rights protection before improvement, thus people hold firm faith of human rights protection. Let people understand the impartiality, fairness, legitimacy, etc. of human rights protection and understand its important position in public right. Some people still hold skeptical attitude for the guarantee of human rights, which means that they do not firmly build up the idea of human rights protection and let the wrong ideology exist in their mind, which seriously affects their own values and wrong interpretation of human rights protection. China, as a country under the rule of law, argues people's autonomy, so the people are the master of the country, who plays a very important role in the rule of law society. People make the laws and use law to safeguard the legitimate rights and interests of their own, so in the country's serve-the-people environment, make consolidate and stable development of the country. Therefore people should hold firm belief of human rights, believe that the improvement of the fair and just system of judicial protection of human rights can not only provide people with fairness and justice, but can make right under the sun and give more good service for public interests, enhance the strength of our country, and safeguard the country's stability. 


\section{IMPROVE THE ABILITY OF THE JUDICIAL PROTECTION OF HUMAN RIGHTS}

\section{A. Treat the deficiency of judicial function rationally}

Our country's judicial function itself is restricted, so social citizen should keep a rational attitude to it, so as to promote the development of China's human rights cause. Our country is now and will be in the primary stage of socialism for a long time, so the judicial protection of human rights should be combined based on China's basic national conditions, clearly see the defective of judicial safeguard, and make rational treatment. There is strict legal system in our country, so the judge cannot create a law, and judicial safeguard has legislative restrictions on human rights. Judicial relief and so on still cannot legislate; therefore our country's system of judicial protection of human rights has larger space improvement and needs further improvement. Nowadays human rights issues in fact are not only in the sense of human rights, but have risen to the level of economic or social level. In the face of such situation, we should increase the speed of our country's economy and culture development, and lay good economic and cultural foundation for the development of the cause of human rights.

\section{B. Establish and improve judicial right operation and supervision mechanism}

Judicial protection system of human rights should not only guarantee the rights of the victim, but also guarantee the accused person's human rights. In order to achieve fair and justice, there is a need to establish and perfect judicial operation and supervision mechanism, which may have the effect of check and balance.

\section{Supervision mechanism requires constraints between rights}

So-called supervision is to supervise and restraint right organizations to make them function and right in the sun. This requires jurisdiction, legal supervision and indictment rights should have a clear division of labor in particular, and let them not only reasonable match but also constrain each other. Reasonable matching mentioned above is to cooperate for the same goal of correct implementation of this law, not to say that what the authority of leadership say and do under the unfair condition need your active cooperation. So in establishing and perfecting judicial right operation and supervision mechanism, make right conditionality.

\section{Supervision mechanism requires right restricting right}

In judicial cases, in order to let the accused person have the guarantee of human rights, there are his enforcement right, his lawyer's investigation and defend right, even myriad people's right of judicial supervision in the society should be set in the end.

\section{Strengthen the judicial competence and function}

Now the level of judicial relief is limited and is not practically carried out. In order to improve judicial protection system of human rights, judicial relief level should be improved. The court will have to bear the responsibility and fully play its part to ensure the execution of procuratorial and judicial authority can be separated. As a country under the rule of law, in the line construction of society under the rule of law and the government by law, trial and judgment of judicial cases exist as the final solution. Under such conditions, the width of the judicial relief should be increased in a certain way, and establish and improve the operation of judicial right restriction and supervision mechanism. Nowadays, judicial personnel initiate wrong idea and do things not conforming to the law because of emotions, property, and their unique rights. The procuratorial and jurisdiction authority get independent operation under the leadership of the communist party of China, and actively promote the development of the great cause of the communist party.

\section{SOLVE THE PROBLEMS EXISTING IN JUDICIAL PROTECTION OF HUMAN RIGHTS}

\section{A. To solve the judicial protection of human rights, we have to improve the judicial mechanism}

The development of society asks the market economy as dominant factor, and human rights are much more than about the human rights of the individual, and the problem of environment resources, climate and commodity and land problems and so on are not mere personal rights but relate to collective human rights, so group or collective human rights become more important. Now the continuous development of society and economy makes the question of human rights rise to economic, cultural and social level, and some of the problems existing in social life have a lot to do with citizen's personal rights. We should establish protection mechanism related to the rights and interests of the collective, thus proving the judicial occupies an important position and needs to be improved. Improvement of the judicial 
mechanism must have authority, efficiency and absolute fairness, and the ultimate goal is for people's interests and to guarantee the most essential right of the people.

\section{B. Judicial protection of human rights requires the improvement of the system}

In order to solve the defects in judicial protection of human rights in judicial organization system, we should improve it. The reform of judicial activities is to co-ordinate, manage and organize so a committee is particularly necessary. The establishment of such a committee is to formulate relevant policies and make harmonious unification of rule of law and supervise the implementation, etc., so that justice can very good safeguard human rights.

\section{Judicial protection of human rights asks for higher entry requirements}

The execution extent of judicial protection system of human rights depends greatly on the inherent quality of the judiciary and its ability to execute judicial cases, so judicial protection of human rights requires that the judiciary entry requirements for judicial organizations should be greatly improved to strengthen the overall level of judicial organizations. Now there are good and bad level professional intermingled in the judiciary, because different requirement of each position. In the face of such a big difference, to improve the judicial personnel's overall quality and level are more difficult. For this reason, we need to take some measures to improve it.

1. Improve the examination system

The judiciary workers come to the judicial organizations by the manner of civil servants talents selection and judicial examination talent selection. But now the two ways of selecting talent have some deficiency and need for reform. Some civil servants' professionalization level is relatively low, which seriously influences the improvement of our country's judicial quality in judicial organization as a whole. In order to solve this problem, for the position of lawyers, judges and prosecutors, take the national unified judicial system under the unified test situation. Catch on the one hand, and take one way of judiciary, a channel selection for the overall improvement of the professional level for the judicial organizations in our country. But there are still civil service exam in our country, and civil service pays more attention to the administrative aspects of the thinking ability, and the judiciary personnel requirement is rational thinking, and illustrate the fact with the law, so civil servants talent selection and talented persons judicial offices need still have a certain difference. So the examination of judicial organization can adopt the other way than civil service personnel to let the overall level of the judiciary personnel to be able to get promoted.

2. Judiciary personnel's professional quality

In the selection of talent, not only choose staff with superb judicial ability, but with lofty professional ethics. For already existed judicial personnel in judicial organizations, improve their knowledge of judicial knowledge structure, the most basic professional ethics, law literacy and the ability to handle judicial case, and finally let them have such professional quality and provide good service for the people.

\section{CONCLUSION}

The improvement of judicial protection system of human rights is to be on the basis of the existing system of judicial protection of human rights, actively implement and maintain the excellent system, and correct and perfect the shortcomings of the system. That is to get the essence of the original system, drop its dregs, perfect the judicial protection of human rights system, and let the public service for the people. In general, we should put human rights in the rule of law, and let human rights work in the rule of law. Let the people to maintain their own rights with laws and institutions and let the people realize their human rights in judicial guarantee.

\section{REFERENCES}

[1] Shen Deyong. Insist on fair justice, respect and protect human rights [J]. China's National People's Congress, 2012 (12).

[2] Zhu Liheng. Public trial research [M]. Beijing: Chinese People's Public Security University Press, 2007.

[3] Jiang Wei. Improve judicial protection system of human rights [N]. The Guangming Daily, 2013-11-19 (1).

[4] Qin Qianhong. From human rights legislation safeguard to human rights judicial protection [N]. The Southern Metropolis Daily, 2013-11-20 (1). 